\title{
Pulmonary cancer and hypertrophic osteoarthropathy Brief recurrence of the osteoarticular symptoms after surgical ressection
}

Instituto do Câncer Arnaldo Vieira de Carvalho - São Paulo, Brazil

A case of adenocarcinoma of the lung in a 57 years old patient associated with hypertrophic ostearthropathy is reported by the authors. The paraneopiastic manifestation occurred after the pulmonary symptoms and receded spontaneously after a right inferior

lobectomy was performed. Osteoarticular symptoms returned near after a tumoral recurrence. Articular pains disappeared 48 hours after the tumoral recurrence ressection of the chest wall and clubbing disappeared completely after the $3 \mathrm{rd}$. week.

UNITERMS: Pulmonary cancer. Adenocarcinoma. Hyperthrophic. Osteoarthropathy.

\section{INTRODUCTION}

$\mathrm{D}$ escribed for the first time in 1868, hypertrophic osteoarthropathy $(\mathrm{OAH})$ can be defined as a syndrome characterized by proliferative chronic periostitis of the long bones, digital clubbing, artritis, synovitis and arthralgia and, many times, causing incapacity.

Within the neoplastic diseases related to $\mathrm{OAH}$, pulmonary cancer is a prominent one. Osteoarticular manifestations may precede the pulmonary in several months and, as the clinic condition is invariably subestimated and understood as being a rheumatic disease, we can frequently observe a delay in the bronchial cancer diagnosis (6).

Literature describes the frequent association of this syndrome to the bronchial adenocarcinoma and considers as very unusual the concomitance with indisctinct carcinoma of little cells (1).

The case presented illustrates clearly the $\mathrm{OAH}$ shades and the interference in the treatment of the osteoarticular symptoms development. 


\section{PRESENTATION}

CBR, 57 years, white, actor, since the end of July 1991, began to claim on insidious and progressive pains at the dorsal region of the right hemithorax. Some weeks after, he noticed digital clubbing of the hands and legs, besides articular ankle pains and a slight local edema. Persistence of the thoracic pains caused his visit to a physician who identified, radiologically, a small mass projected in direction to the apical segment of the right inferior lobule, understood as being a consequence of some specific process. In the next radiological control procedures, a progressive increase of the injury was observed, followed by more intensive thoracic pains and arthralgia. The bronchoscopy and transparietal pulmonary biopsy done were not conclusive. Due to the diagnose indefinition, in January 14, 1992, a exploring thoracotomy was done. The presence of an adenocarcinoma in the right inferior lobule was identified. Inferior lobectomy with ressection of the costal arches in blocks was done (surgical duration $=\mathrm{T} 2 \mathrm{~N} 0$ ). A complete disappearing of $\mathrm{OAH}$ was observed 30 days after surgery.

October, 1992 on, patient observed again thoracic pains in the same local previously described and increasing progressively. He also observed the return of the clubbing of the extremities, pain in axles and knees, followed by a local edema and phlogystic manifestation, besides difficulty in movements as a consequence of the arthralgia. Tumor recurrence on the posterior right wall of the chest was confirmed in May, 1993. Patient was submitted to a ressection of the segment of the thoracic wall involving three costal arches and comprising in its totality the tumor recurred in July 19, 1993. Two days after surgery the patient informed a complete disappearing of the arthralgia and the phlogystic manifestation. Digital clubbing disappeared completely after three weeks.

\section{COMMENTS}

The case above is quite illustrative in what refers to delay in the pulmonary neoplasia diagnose when manifestations and symptoms of rheumatic diseases are associated to it. Tumor recurrence confirmation was difficult as well, although paraneoplastic syndrome has acted as a real biological marker.

Literature describes recurrence of the osteoarticular symptoms even four times after the neoplasia treatment. Complete disappearing of the arthralgia within the first 48 hours after ressection of tumor called the attention. This should probably be a result of the sudden reduction of the serum levels of substances with chemical structure similar to the hormones produced by neoplasia. In $\mathrm{OAH}$ manifestations, increase in the serum levels of the following hormones is made reference: growth (3) and estrogen (4). More recently, presence of a substance in the granule plaques has been identified as capable of changing the characteristics of the endothelium-plaque unity, causing modifications in the microvascular system of the extremities. This substance is nominated as the growth factor derived from plaques (PDGF)(7).

Although surgery in what refers to oncologic terms is more adequate and efficient in the control of neuroplastic diseases and consequently of the $\mathrm{OAH}$, recurrence of the syndrome is experienced in both chemotherapy (5) and in radiotherapy, tumor even not being completely exterminated (2). In this circumstance, it is probable that therapy changes the biological behavior of the remaining tumor. So, even in patients where neoplasia can not be faced surgically, other treating manners should be tried, even if only with palliative purpose, with the objective of minimizing the symptoms caused by the paraneoplasia syndrome. 


\section{RESUMO}

Objetivo: Os autores apresentam caso de adenocarcinoma de pulmāo em paciente de 57 anos associado a osteoartropatia hipertrófica. Discussão: A síndrome paraneoplásica surgiu após o início dos sintomas pulmonares e regrediu espontaneamente depois da realização de lobectomia inferior direita. Resultados: Os sintomas osteoarticulares reapareceram em seguida a recidiva tumoral. As dores articulares desapareceram passadas 48 horas da ressecção do tumor recidivado na parede torácica e o baqueteamento digital regrediu completamente após a terceira semana.

\section{REFERENCES}

1. BUNN, P.A. \& MINNA, J.D. - Síndromes paraneoplásticos. Em De Vita Jr., V.T., Hellman, S., Rosenberg, S.A. - Cancer. Princípios y práctica de oncologia. España, Salvat Editores S.A., 1673-1715, 1988.

2. CAMPEAU, R.J.; ROSALES, O.R.; GARCIA, O.M. \& CORREA, O.A. - Resolution of hyperthrophic pulmonary osteoarthropathy after radiotherapy in the absence of lung tumor response. Clin Nucl Med 14: 453-455, 1988.

3. GOSNEY, M.A.; GOSENY, J.R. \& LYE, M. - Plasma growth hormone and digital clubbing in carcinoma of the bronchus. Thorax 45: 545-547, 1990.
4. ORTEGA, S.S.; LEDESNA, J.C.; CEBRIAN, J.F. \& CRUZ, A.L. - Osteoartropatia hipertrofica, ginecomastia y arañas vasculares, en relacion con la aumentada produccion de estrogenos como manifestacion inicial de un carcinoma epidermoide del pulmon. Rev Clin Esp 187: 372-374, 1990.

5. PUJOL, J.L.; NOYOLA, A.; PARRAT, E.; DAN-AOUTA, M. \& GODARD, P. - Regression d'un hipocratsme digital au cours de la chimiotherapie d'un cancer bronchique. Rev Pneumol Clin 47: 57-58, 1991.

6. SILVA, P.P.A.; PEREIRA, J.R.; IKARI, F.K. \& MINAMOTO, H. - Câncer de pulmão e retardo no diagnóstico: análise de 300 casos. Rev Ass Med Brasil 38: 145-149, 1992.

7. SILVERI, F.; CARLINO, G. \& CERVIN, C. - The "endotelium/platelet unit" in hyperthrophic oesteoarthropathy. Clin Exp Reumatol 10 (Suppl): 61-66, 1992. 